\title{
Milk Production and its Marketing in Mizoram- Findings from Aizawl District
}

\author{
Lalhmangaihsangi Ralte and Vanlal Chhawna*
}

Department of Economics, Mizoram University, Mizoram, India

*Corresponding author: vchhawna@gmail.com (ORCID ID: 0000-0002-1466-740X)

Received: $12-09-2021$

Revised: 21-11-2021

Accepted: 14-12-2021

\begin{abstract}
The present study examined the economics of milk production in Mizoram with reference to input-output relationship, cost-benefits ratio and marketing channels, using stratified sampling technique to select the sample farmers according to the herd size. Descriptive statistical tools and regression models have been used to analyse the data. Although dairy farming requires a large amount of capital for starting up and monthly average variable cost also being very high, returns from sale of milk and other sources produce a sizeable amount of income to the cattle farmers. Findings show that the dairy farming was found to be profitable activity which is justified by its cost-benefit ratio which is greater than one (1.7). Dairying farming has been subject to decreasing returns to scale. Dairy farmers are faced with various kinds of constraints. Appropriate measures are suggested to address these constraints in order to enhance the profitability and viability of dairy farming and to develop the sector as a whole.
\end{abstract}

HIGHLIGHTS

(- Dairying farming is a profitable economic activity, contributing stable income and employment to the household economy. The dairy sector offered alternative livelihood potential to shifting cultivators.

Keywords: Production function, cost-benefit ratio, marketing channels, Aizawl

Dairy sector provides sustainable employment and income in rural areas in several countries across the world. Milk in developing countries are produced mainly in small-scale farming systems, contributing to household livelihoods, food security and nutrition (FAO, 2021). During 2016-17, India's livestock sector accounted for approximately 4 per cent of the national income and 26 per cent of the total output from agriculture sector; and dairy farming itself constituted 67 per cent of livestock output (Central Statistical Organisation, 2018). India is one of the world's largest producers and consumers of milk, contributing 19 percent of global milk production; about 70 million farmers in rural areas were involved in milk production, generating more than one-third of their gross income (Department of Animal Husbandry and Dairying, 2018). India has the largest population of dairy cattle in the world
(Mullan et al. 2020). Over the last few decades, the Indian dairy sector witnessed significant growth and development. Due to the positive and significant contribution of the sector in the Indian economy, both central and state governments have taken several initiatives to develop dairy sector. The dairy sector in the north-eastern states showed poor performance, indicating modest growth rate over the years and milk production have remained lagging behind relative to other states. Meanwhile, household demand for milk and milk products rose rapidly in recent years in the region due to increase in income and lifestyle changes (Feroze et al. 2010).

How to cite this article: Ralte, L. and Chhawna, V. (2021). Milk Production and its Marketing in Mizoram- Findings from Aizawl District. Economic Affairs, 66(04): 699-705.

Source of Support: None; Conflict of Interest: None (2) 9 
During the last three decades, Mizoram witnessed increasing activities in dairy farming, especially in urban and semi-urban areas. As on 2017-18, milk production was 25 thousand tonnes (table 1). Milk production came mostly from Holstein Friesian and Jersey cattle. About 91per cent milk production is contributed by crossbred cows and the rest 9 per cent by indigenous cows(Planning and Programme Implementation Department, 2019). Milk consumption is very low in Mizoram; it was only 63 grams of milk per day per individual in the state. Only 9 villages have been identified as milk potential villages out of 830 villages across the state. Only 8.75 per cent of total milk production in the state was procured by Dairy Cooperatives Societies, showing that dairy farmers directly sold more than 90 per cent of their products to the household consumers. The data suggested that dairy sector is underdeveloped and the state needs to make tremendous efforts to achieve self-sufficiency in milk production and sustainable development of dairy sector.

Table 1: Status of Dairy Sector in Mizoram

\begin{tabular}{|c|c|c|}
\hline S1. No. & Parameter & Quantity \\
\hline 1 & $\begin{array}{l}\text { Milk Production 2017-18 } \\
\text { (in 000tonnes) }\end{array}$ & 25.02 \\
\hline 2 & $\begin{array}{l}\text { Per capita Availability 2017-18 } \\
\text { (in gram/day) }\end{array}$ & 63 \\
\hline 3 & $\begin{array}{l}\text { Total Number of Villages } \\
\text { (2011 Census) }\end{array}$ & 830 \\
\hline 4 & $\begin{array}{l}\text { Number of Milk Potential Villages } \\
\text { (\% of total no. of villages) }\end{array}$ & $9(1.08 \%)$ \\
\hline 5 & $\begin{array}{l}\text { Number of organized Dairy } \\
\text { Cooperative Societies (DCS) }\end{array}$ & 39 \\
\hline 6 & $\begin{array}{l}\text { Number of Milch Animal Owning } \\
\text { Households (MAHin Lakh) }\end{array}$ & 0.05 \\
\hline 7 & $\begin{array}{l}\text { Number of Farmer members enrolled } \\
\text { under DCS }\end{array}$ & 950 \\
\hline 8 & $\begin{array}{l}\text { Average Milk Procurement by DCS } \\
\text { (in TKgPD) (\% of Milk Production }\end{array}$ & $6(8.75 \%)$ \\
\hline \multirow[t]{2}{*}{9} & Chilling Centres Number & - \\
\hline & Capacity (TLPD) & - \\
\hline \multirow[t]{2}{*}{10} & Bulk Milk Cooler Number & 11 \\
\hline & Capacity (TLPD) & 11 \\
\hline \multirow[t]{2}{*}{11} & Processing Plants Number & 1 \\
\hline & Capacity (TLPD) & 20 \\
\hline
\end{tabular}

Source: State Dairy Profiles/Dairy Development Schemes, Department of Animal Husbandry and Dairying, Ministry of Fisheries, Animal Husbandry and Dairying. Government of India.
The agriculture sector, mostly based on shifting cultivation, which employed more than 50 per cent of the workers, has been adversely affected by population growth and climate change (Sati, 2019). As public sector employment have been limited and industrial sector is not yet pick up in the state, livestock sector, especially dairy sector, is one of the potential sectors for generating sustainable livelihood and food security in the state. The present study has been undertaken to examine the social and economic conditions of dairy farmers, marketing channels of dairy milk products, cost and benefit situations, production conditions and the constraints faced by dairy farmers.

\section{MATERIALS AND METHODS}

The present study was conducted in Aizawl district during 2019-20, which was the largest producer of milk in the state, accounting for 56 per cent of the total milk production (Planning and Programme Implementation Department, 2019). Durtlang, a local council are a under Aizawl Municipal Corporation (AMC) and Sihphir village were purposively selected because they are the main milk producing centres in the district. During 2011 census, there were 2076 households in Durtlang while Sihphir had 1300 households. Stratified sampling technique was adopted to select the sample farmers according to the herd size owned by them. Data were obtained from 40 respondent farmers, covering 214 household members, using pre-tested questionnaire. Secondary data were collected from various public sources and agencies.

Descriptive statistical tools such as mean, standard deviation, percentage, and frequency counts and regression models have been used to analyse the data. To examine the input-output relationship, Cobb-Douglass production function in its log-linear form has been fitted to the data as follows:

$$
\operatorname{LnYi}=\alpha+\beta_{1} \ln X_{1 i}+\beta_{2} \ln X_{2 i}+\beta_{3} \ln X_{3 i}+\beta_{4} \ln X_{4 i}+\mu_{1}
$$

where $Y i=$ value of milk output (₹); $X_{1}=$ expenditure of animal concentrates (₹); $X_{2}=$ expenditure of animal feeds; $X_{3}=$ wages of labour, both direct and family labour; $X_{4}=$ expenditure of miscellaneous inputs and $u i=$ disturbance term/random variable. The value of output and inputs are indicated in terms of per cow per day. The coefficients $\beta_{1^{\prime}} \beta_{2^{\prime}} \beta_{3}$ 
$\& \beta_{4}$ represent the partial elasticity of output with respect to the input used. The sum of the coefficients indicates about the returns to scale. There are constant returns to scale if the sum is equal to 1 , decreasing returns to scale if the sum is smaller than 1 and increasing returns to scale if the sum is greater than 1 . The model is linear in the parameters $\alpha, \beta_{1^{\prime}} \beta_{2^{\prime}} \beta_{3^{\prime}} \& \beta_{4}$ and is therefore a linear regression model (Gujarati \& Sangeetha, 2009).

\section{RESULTS AND DISCUSSION}

\section{Socio-economic backgrounds of dairy farmers}

Tables $2 \& 3$ show the socio-economic profile of the dairy farmers. Out of 40 respondents, 37 were males and 3 females. The average family size was 5.35 people per family. The mean age of the respondent was 54 years; the age of the respondent farmers varied between a minimum of 33 and a maximum of 67 years. The educational level of the respondents indicated that 40 per cent completed high school, 32.5 per cent middle school, 20 per cent primary school and 7.5 per cent higher secondary level. Years of experience varied between 6 and 36 years with a mean of 17 years. Around 67.5 percent of respondents lived in semi-pucca houses while 32.5percent in pucca houses. All dairy households belonged to Above Poverty Line family. Most farmers (67.5\%) relied on family labour; only 13 (32.5\%)farmers engaged outside labour. The analysis indicated that cattle farmers were educated, had adequate experience in the dairy farming and well established in terms of housing and economic status. Other studies also found that dairy farmers derived sustained livelihood, income, employment, and nutritional security (Gururaj, 2014; Kumar \& Parappuratha, 2014).

Table 2: Socio-Economic Profile of the Respondents

\begin{tabular}{llll}
\hline $\begin{array}{l}\text { S1. } \\
\text { No. }\end{array}$ & Parameter & Frequency & Percent \\
\hline 1 & Gender & 40 & 100 \\
\hline & Male & 37 & 3 \\
& Female & 3 & 19 \\
\hline 2 & Total household members & 214 & 100 \\
\hline 3 & Average family size & 5.35 & - \\
\hline 4 & Age of the respondents & & \\
\hline & Mean age & 53.78 & - \\
& Minimum age & 33 & -
\end{tabular}

\begin{tabular}{|c|c|c|c|}
\hline & Maximum age & 67 & - \\
\hline \multirow[t]{5}{*}{5} & Educational Level & & \\
\hline & Primary school & 8 & 20 \\
\hline & Middle School & 13 & 32.5 \\
\hline & High School & 16 & 40 \\
\hline & Higher Secondary School & 3 & 7.5 \\
\hline \multirow[t]{3}{*}{6} & Housing Type & & \\
\hline & Pucca House & 13 & 32.5 \\
\hline & Semi-pucca & 27 & 67.5 \\
\hline \multirow[t]{4}{*}{7} & $\begin{array}{l}\text { Years of experience in } \\
\text { dairying farming }\end{array}$ & & \\
\hline & Mean years & 17 & - \\
\hline & Minimum years & 6 & - \\
\hline & Maximum years & 36 & - \\
\hline \multirow[t]{3}{*}{8} & Poverty status & & \\
\hline & Above Poverty Line & 40 & 100 \\
\hline & Below Poverty Line & Nil & Nil \\
\hline \multirow[t]{4}{*}{9} & Persons operating the farm & & \\
\hline & Family alone & 27 & 67.5 \\
\hline & Only employed labour & 1 & 2.5 \\
\hline & Family with employed labour & 12 & 30 \\
\hline
\end{tabular}

Source: Field surveyed data 2019.

As given in Table 3, the total household members of the dairy farmers were 214 persons, male members accounting for 53.27 per cent and female members 46.73 per cent. The educational levels of the household members indicated that 32.71 per cent completed high school education, 19.16 per cent middle school, 18.69 per cent primary school and 10.28 per cent graduate and above. The occupational status showed that 32 percent are directly engaged in dairy farming, 15.42 per cent in agriculture-related activities while other members were engaged in government services $(2.80 \%)$, private enterprises $(2.80 \%)$, small trade \& business $(1.87 \%)$, and wage labourer (2.34\%). Non-working household members accounted for 43 per cent of the population. The analysis indicated that dairy household members follow diversified occupations that help to improve the economic condition of the family.

Table 3: Profiles of Household Members of Dairy Farmers

\begin{tabular}{llll}
\hline S1. No. Particulars & \multicolumn{2}{l}{ Frequency Per cent } \\
\hline 1 & Gender & 214 & 100 \\
\hline \multirow{2}{*}{ Male } & 114 & 53.27 \\
& Female & 100 & 46.73 \\
\hline 2 & Educational Level & & \\
\hline \multirow{4}{*}{ Primary school \& below } & 40 & 18.69 \\
& Middle school (upto class VII) & 41 & 19.16 \\
& High school (upto class X) & 70 & 32.71
\end{tabular}




\begin{tabular}{|c|c|c|c|}
\hline & $\begin{array}{l}\text { Higher Secondary school } \\
\text { (upto class XII) }\end{array}$ & 41 & 19.16 \\
\hline & Graduate \& above & 22 & 10.28 \\
\hline \multirow[t]{8}{*}{3} & Occupational status & & \\
\hline & Dairying farming & 68 & 31.78 \\
\hline & Agriculture & 33 & 15.42 \\
\hline & Trade \& business & 4 & 1.87 \\
\hline & Government services & 6 & 2.80 \\
\hline & Private services & 6 & 2.80 \\
\hline & Wage labourer & 5 & 2.34 \\
\hline & Others & 92 & 42.99 \\
\hline
\end{tabular}

Source: Field surveyed data 2019.

Table 4 represents the distribution of farm size in terms of number of cattle. A total of 301 individual cows were observed, ranging from 4 to 13 cows per dairy farm. Majority of cattle $(67.4 \%)$ were milch cows, while heifers accounted for 16.61 per cent and calves 16.0 per cent. Dairy farmers were categorised into four groups according to cattle population owned by them. These include farmers having less than 5 cows, farmers having 5 to 8 cows, farmers having 9 to 12 cows and farmers having more than 12 cows. It was observed that there were 8 farmers with a total of 32 cows under farm size less than 5 . The average herd size was 4 cows per family. The farm size between 5 and 8 contained 18 farmers, having 115 cows with 6.4 cows per farm. A total of 10 farmers belonged to $9-12$ cow size, having 102 cows with 10.2 per farm. Under farm size more than 12 cows, there were 4 farmers with 52 cows, i.e., 13 per farm. The average farm size was 7 cows per farmer. The dairy farm structure showed that the average herd size is greater than the average Indian dairy herd which usually consists of 2 animals while over 80 per cent farmers keep 2 to 8 animals (Hemme et al. 2003).

Table 4: Distribution of cows and farmers according to farm size

\begin{tabular}{lllll}
\hline $\begin{array}{l}\text { S1. } \\
\text { No. }\end{array}$ & Farm size & $\begin{array}{l}\text { Number } \\
\text { of cows }\end{array}$ & $\begin{array}{l}\text { Number } \\
\text { of farmer }\end{array}$ & $\begin{array}{l}\text { Average } \\
\text { cattle per } \\
\text { farm }\end{array}$ \\
\hline 1 & Less than 5 & 32 & 8 & 4 \\
2 & 5 to 8 & 115 & 18 & 6.4 \\
3 & 9 to 12 & 102 & 10 & 10.2 \\
4 & More than 12 & 52 & 4 & 13 \\
\hline & Total & 301 & 40 & 7.5 \\
\hline
\end{tabular}

Source: Field surveyed data 2019.

\section{Marketing Channels}

The marketing channels comprise of door to door distribution, i.e., direct sale at home for regular customers and sale to cooperative units. Table 5 indicates that cooperative channel served 21 farmers $(52.5 \%)$ and door-to-door channels 19 farmers $(47.5 \%)$. The price of milk varies between the channels of distribution and as also between the two localities. The price of milk for door-to-door channel was ₹ 70 per litre in Durtlang and ₹ 60 per litre in Sihphir. As many as 14 farmers from Durtlang and only 5 farmers from Sihphir village used door-todoor channel. Durtlang farmers have access to direct consumers in Aizawl city and realised better prices while Sihphir farmers, being located farther away from the city, do not get that opportunity.

Table 5: Farmers and their marketing channels

\begin{tabular}{llll}
\hline Channel & $\begin{array}{l}\text { Dairy farmers } \\
\text { from Durtlang }\end{array}$ & $\begin{array}{l}\text { Dairy farmers } \\
\text { from Sihphir }\end{array}$ & $\begin{array}{l}\text { Total dairy } \\
\text { farmers }\end{array}$ \\
\hline $\begin{array}{l}\text { Door to } \\
\text { Door }\end{array}$ & 14 & 5 & 19 \\
$\begin{array}{l}\text { Cooperative } \\
\text { Unit }\end{array}$ & 6 & 15 & 21 \\
\hline Total & 20 & 20 & 40 \\
\hline
\end{tabular}

Source: Field surveyed data 2019.

The prices of milk varied between $₹ 43.00$, ₹ 45.00 and ₹ 48.00 in the cooperative sector. Farmers are paid according to the milk quality as measured by the representatives of the cooperative society. Cooperative sectors have been observedless efficient relative to door-to-door distribution where direct sale of milk at home fetched competitive and better prices to the farmers. This revealed that, although less efficient, cooperative units served an important marketing channel for dairy farmers in Sihphir village. Although cooperative sectors offer lower prices, milk producers relied more on them because of sustained demand from these sources and due to a perception of higher reliability (Gururaj, 2014; Kumar \& Parappuratha, 2014).

\section{Cost-Benefit Ratio Analysis}

Table 6 indicates the cost-benefit indicators of dairy farming, where the variable costs for different farm size was estimated were ₹ 181, ₹ 201, ₹ 187 and ₹ 198 per cow per day,respectively. The overall average variable cost was estimated at $₹ 192$ per cow 
per day. Again, net incomes from milk production were ₹ 304, ₹ 279, ₹ 239 and ₹ 390 per cow per day, respectively. The average net income for all sizes taken together was ₹ 303 per cow per day. Variation in net income from different herd size was due to price differentials in different channels of distribution and also due to number of milch cows per farm. Farmers, having access to door-to-door distribution or off-farm channels where prices are more efficient, derived optimum returns per milch cows (Kumar \& Parappuratha, 2014).

Farmers derived income from sale of cow dung, meats, etc., the total net incomes accrued including other sources were ₹ 336, ₹ 328, ₹ 245 and ₹ 396 for different farm size while the benefit-cost ratios for each farm size were 1.9, 1.6, and 1.3, and 2 respectively. The cost-benefit ratio was the highest in respect of the farm size more than 12 animals and lowest for farm size 9-12 animals. The overall cost-benefit ratio was estimated at 1.7. The results showed that dairying farming is a profitable enterprise, significantly contributing to the household economy.

\section{Production Function Analysis}

The descriptive statistics of the expenditure of inputs used in milk production are highlighted in table 7 . The average expenditure on animal concentrates per cow per day was ₹ 107.83 with standard deviation of ₹ 28.60. The expenditure on these items varied between a minimum of ₹ 55.43 and a maximum of ₹ 161.67 per cow per day. The expenditure on animal feeds varied between ₹ 8.33 and ₹ 102.82 per cow per day with an average of $₹ 35.56$ and standard deviation of ₹ 29.14. The average expenditure on labour wages was $₹ 45.51$ per animal per day while expenditure on miscellaneous items was ₹ 42 per animal per day. The degree of variation, as measured by the coefficient of variation $(\mathrm{CV})$, showed that expenditure on input used in the milk production varied between 26 per cent in respect of animal concentrates and 82 per cent in respect of animal feeds. The data showed that animal concentrates have been found to be the most expensive one among the inputs used for milk production.

Table 6: Cost-Benefit indicators in dairy farming per animal per day (₹)

\begin{tabular}{|c|c|c|c|c|c|}
\hline \multirow{2}{*}{ Particulars } & \multicolumn{5}{|c|}{ Farm Size } \\
\hline & Less than 5 & 5 to 8 & 9 to 12 & More than 12 & Total \\
\hline Expenses on variable items (A) & 181 & 201 & 187 & 198 & 192 \\
\hline Expenses on fixed items (B) & 57750 & 64952 & 29798 & 36240 & 47185 \\
\hline Gross Income from Milk (C) & 484 & 480 & 426 & 588 & 494 \\
\hline Net income from milk (D) & 304 & 279 & 239 & 390 & 303 \\
\hline Benefit- Cost ratio (milk) & 2 & 1 & 1 & 2 & 2 \\
\hline Income from sale of cow dung, etc. (E) & 32 & 49 & 6 & 6 & 23 \\
\hline Total income from dairy farming $(\mathrm{F})$ & 516 & 529 & 432 & 594 & 518 \\
\hline Net Income from dairy farming (F-A) & 336 & 328 & 245 & 396 & 326 \\
\hline Benefit-Cost ratio of dairy farming $(\mathrm{F}-\mathrm{A}) \div \mathrm{A})$ & 1.9 & 1.6 & 1.3 & 2 & 1.7 \\
\hline
\end{tabular}

Source: Author's calculation from field surveyed data 2019.

Table 7: Descriptive statistics of inputs used (₹)

\begin{tabular}{llllll}
\hline Expenditure on Inputs used & Average & Standard Deviation & Maximum & Minimum & Coefficient of Variation (CV) \\
\hline $\begin{array}{l}\text { Expenditure on concentrates per } \\
\text { animal per day }\end{array}$ & 107.83 & 28.60 & 161.67 & 55.43 & 0.26 \\
$\begin{array}{l}\text { Expenditure on feeds per animal } \\
\text { per day }\end{array}$ & 35.56 & 29.14 & 102.82 & 8.33 & 0.82 \\
$\begin{array}{l}\text { Expenditure on labour per animal } \\
\text { per day }\end{array}$ & 45.51 & 14.66 & 66.67 & 20.83 & 0.32 \\
$\begin{array}{l}\text { Expenditure on miscellaneous items } \\
\text { per animal per day }\end{array}$ & 42.05 & 27.80 & 169.50 & 12.79 & 0.66 \\
\hline
\end{tabular}

Source: Author's calculation from field surveyed data 2019. 
Table 8: Cobb-Douglas Production Function for Dairy Farming

\begin{tabular}{lllll}
\hline Variables & Coefficients & Std.Error & t-Statistic & Prob. \\
\hline Constant & 2.6102 & 1.0191 & 2.5612 & 0.0149 \\
Expenditure on concentrates per animal per day $\left(\mathrm{X}_{1}\right)$ & 0.3210 & 0.1711 & 1.8760 & 0.0690 \\
Expenditure on feeds per animal per day $\left(\mathrm{X}_{2}\right)$ & 0.1050 & 0.0321 & 3.2701 & 0.0024 \\
Expenditure on labour per animal per day $\left(\mathrm{X}_{3}\right)$ & 0.0322 & 0.1521 & 0.2118 & 0.8335 \\
Expenditure on miscellaneous items per animal per day $\left(\mathrm{X}_{4}\right)$ & 0.3454 & 0.0976 & 3.5387 & 0.0012 \\
\hline R-Squared & 0.3492 & & \\
\hline Adjusted R-Squared & 0.2748 & & \\
\hline F-statistic & 4.6949 & & \\
\hline Prob (F-statistic) & 0.0039 & & \\
\hline
\end{tabular}

Source: Author's calculation from field surveyed data 2019.

Table 8 shows that the regression coefficient of expenditure on animal concentrates $\left(X_{1}\right)$ was positive and significant at 10 per cent level, indicating that a 1 percent increase in expenditure on these items would increase 32 percent of milk production. The response to expenditure on animal feeds $\left(X_{2}\right)$ was positive and statistically significant at 1 percent level. The contribution of labour $\left(X_{3}\right)$ is positive but not significant which indicates that labour input does not play a significant role in milk production. The value of adjusted R-squared, i.e., 27.48 per cent indicated that about 27 percent variation in output has been explained by the variation of independent variables included in the model. The computed F-statistic is statistically significant as indicated by the significance of $\mathrm{R}^{2}$. The sum of the elasticity coefficients has been less than one, suggesting perhaps that the cattle farms are operating under decreasing returns to scale. More or less similar results have been found in other studies (Lalrinsangpuii \& Malhotra, 2016; Lalrinsangpuii et al. 2016; Singh et al. 2019).

\section{Constraints faced by the farmers}

The different kinds of constraints encountered by dairy farmers, based on their responses are summarised in table 9. High cost of animal feeds and concentrates was the biggest constraint faced by all farmers. Low price of milk was another constraint faced by more than half of the farmers $(52.5 \%)$. Other constraints related to non-availability of workers $(22.5 \%)$, unavailability of animal healthcare facilities (20.0\%), inadequate supply of feeds $(7.5 \%)$, water scarcity $(7.5 \%)$, occupational hazards $(10.0 \%)$ and transportation bottlenecks
(5.0\%). Similar constraints have been observed from studies across the country (Michael et al. 2012; Kumar \& Parappuratha, 2014; Lalrinsangpuii et al. 2016; Sarkar \& Dutta, 2020; Gamit et al. 2021).

Table 9: Constraints faced by dairy farmers

\begin{tabular}{lll}
\hline Constraints & $\begin{array}{l}\text { Number } \\
\text { of farmer }\end{array}$ & Percentage \\
\hline $\begin{array}{l}\text { High costs of animal feeds and } \\
\text { concentrates }\end{array}$ & 40 & 100.0 \\
$\begin{array}{l}\text { Irregular and inadequate supply of } \\
\text { feeds }\end{array}$ & 7.5 \\
$\begin{array}{l}\text { Scarcity of water supply during dry } \\
\text { season (November to May) }\end{array}$ & 7.5 \\
$\begin{array}{l}\text { Unavailability of animal healthcare } \\
\text { facilities }\end{array}$ & 8 & 20.0 \\
$\begin{array}{l}\text { Low price of milk and milk } \\
\text { products }\end{array}$ & 21 & 52.5 \\
$\begin{array}{l}\text { Non-availability of dairy skilled } \\
\text { workers }\end{array}$ & 9 & 22.5 \\
$\begin{array}{l}\text { Occupational Hazards } \\
\text { Transportation and distribution } \\
\text { bottlenecks }\end{array}$ & 2 & 10.0 \\
\hline
\end{tabular}

Source: Field surveyed data 2019.

\section{CONCLUSION}

The analysis revealed that almost half of the farmers $(47 \%)$ completed high school education; and about one-third lived in pucca houses (33\%). Besides, all farmers belonged to above poverty line family. Majority of farmers $(67.5 \%)$ relied on family labour. Milk price varied between ₹ 70 per litre and ₹ 60 per litre in the direct market channel; but more than half of the farmers sold their products to cooperative agencies (52.5\%) where milk price varied between ₹ 43 and ₹ 48 per litre. The overall 
cost-benefit ratio (1.7) showed that dairying farming is a profitable enterprise. The production model showed that animal concentrates and feeds significantly contributed to milk production while labour contribution is positive but not significant; $27 \%$ variation in output has been explained by the independent variables and dairy farms operated under decreasing returns to scale. High cost of animal feeds and concentrates was the biggest constraint faced by farmers. Low price of milk was another constraint faced by more than half of the farmers $(52.5 \%)$.

Since the analysis is confined to a limited geographical area, future research works may focus on the performance of dairy sector under different agro-climatic conditions to derive more broad-based results. Other works may also look into utilisation of public fund for dairy development, adoption of improved technology and scientific dairy farming practices, and animal welfare assessment (Mullan et al. 2020; Rathod \& Dixit, 2021). Several broad policy measures emerged from the study. These include provision of cold storage and processing facilities, diffusion of technical guidance and adoption of scientific dairy farming, cultivation of fodder, strengthening of cooperative society infrastructure, and provision of adequate veterinary facilities at all production levels. At farm level, provision of feed materials especially concentrate feeds at accessible prices to the farmers would go a long way in optimising returns from dairy farming.

\section{REFERENCES}

CSO. 2018. National Accounts Statistics. New Delhi: Government of India. https://mospic.nic.in.

Department of Animal Husbandry and Dairying. 2018. National Action Plan for Dairy Development Vision 2022. Government of India, Ministry of Agriculture and Farmer's Welfare, New Delhi. Accessed from: https:// dadh.nic.in.

FAO. 2021. Gateway to dairy production and products. Rome. Food and Agricultural Organisation. Accessed from: http://www.fao.org/dairy-production-products/ production/en/

Feroze, S.R. 2010. Status of Livestock Sector: A Micro Study of North Eastern India. Ind. J. Hill Farming, 23(2): 43-51.
Gamit, V., Odedra, M., Ahlawat, A., Prajapati, V., Patel, H., and Gamit, K. 2021. Constraints faced by dairy Farmers in Different States of India: An Overview. J. Entomology and Zoology Stud., 9: 1901-1906.

Gujarati, D.N. and Sangeetha. 2009. Basic Econometrics. New Delhi. Tata McGraw Hill Education.

Gururaj, B. 2014. Contribution of Dairy Farming in Employment and Household Nutrition in Drought Prone Areas of Karnaka: A Study of Raichur Districttaka (MSc thesis). National Dairy Research Institute (Deemed University). Karnal. Accessed from: https://docplayer.net

Hemme, T., Garcia, O. and Saha, A. 2003. A Review of Milk Production in India with Particular Emphasis on Small-Scale Producers. Rome. Food and Agricultural Organisation Accessed from: http://www.fao.org/3/bp233e/bp233e.pdf.

Kumar, A. and Parappuratha, S. 2014. The Economics of Dairy Farming and Marketing: Micro-level perspectives from three major milk producing states of India. Int. J. Anim. Sc., 84(2): 204-209.

Lalrinsangpuii, and Malhotra, R. 2016. Resource Use Efficiency in Milk Production in Mizoram State of North East India. J. Anim. Res., 6(3): 431-435.

Lalrinsangpuii, Malhotra, R. and Priscilla, L. 2016. Economics of Milk Production and its Constraints in Mizoram. Indian J. Dairy Sc., 60(5): 558-594.

Michael, K.L. 2012. Economics of Milk Production and its Constraints in Nagaland. Indian J. Dairy Sc., 65(6): 520-526.

Mullan, S., Bunglavan, S., Rowe, E., Barret, D., Lee, M., Ananth, D. and Tarlton, J. 2020. Welfare Challenges of Dairy Cows in India Identified Through On-Farm Observations. Animals, 10: 586.

Planning and Programme Implementation Department. 2019. Economic Survey. Aizawl: Government of Mizoram. Available from: https:///planning.mizoram.gov.in

Rathod, P.K. and Dixit, S. 2021. Precision Dairy Farming: Opportunities and Challenges for India. Indian J. Anim. Sc., 90(8): 1083-1094.

Sarkar, A. and Dutta, A. 2020. Challenges and Opportunities of dairy sector in India vis-a-vis world. Exploratory Anim. and Med. Res., 10(1): 9-17.

Sati, V.P. 2019. Economic and Ecological Implication of Shifting Cultivation in Mizoram, India. Switzerland: Springer. https://doi.org/10.1007/978-3-030-36602.5

Singh, O.K., Singh, Y., Singh, K.R. and Singh, N. 2019. Economics of Milk Production and Marketing in Thoubal District of Manipur, India. Int. J. Curr. Microb. and Appl. Sc., 8(06): 1397-1407. 
